\title{
CELE PREWENCYJNE ZARZĄDZANIA RYZYKIEM POWODZIOWYM W PRAWIE OCHRONY ŚRODOWISKA
}

\author{
PREVENTIVE GOALS \\ OF FLOOD RISK MANAGEMENT \\ IN ENVIRONMENTAL LAW
}

http://dx.doi.org/10.12775/PPOS.2014.041

\section{STRESZCZENIE}

W systemie regulacji dotyczących gospodarki wodnej w prawie ochrony środowiska ważnym zadaniem o znaczeniu ogólnogospodarczym jest utworzenie jednolitego systemu zarządzania ryzykiem powodziowym opartego na metodach prawno-ekonomicznych. System taki według założeń powinien zlikwidować brak prewencji w ochronie

* Dr hab., prof. UŁ, kierownik Zakładu Prawa Ochrony Środowiska, Katedra Prawa Administracyjnego i Nauki Administracji, Wydział Prawa i Administracji, Uniwersytet Łódzki, sędzia WSA w Warszawie. 
przed powodzią i pozwolić na wprowadzenie jednolitego systemowego podejścia metodycznego $\mathrm{w}$ zarządzaniu ryzykiem powodziowym. Utworzenie wspólnego systemu zarządzania ryzykiem powodziowym będzie jednym $\mathrm{z}$ trudniejszych zadań realizowanych $\mathrm{w}$ najbliższej przyszłości. Obecnie tworzone są jego podwaliny. Zbudowanie takiego systemu wymaga w pierwszej kolejności opracowania ogólnego modelu prawnego ochrony przed powodzią stanowiącego podstawę zarządzania ryzykiem powodziowym. Model taki będzie opierać się na obowiązujących już aktach prawnych dotyczących ochrony wód oraz będzie czerpać z całości doświadczeń nagromadzonych w procesie stosowania przepisów regulujących gospodarkę wodną. Jest to także zagadnienie niezwykle ważne dla skuteczności instrumentów prawa ochrony środowiska w zapobieganiu skutkom powodzi.

\section{Słowa kluczowe}

System regulacji; prawo ochrony środowiska; zarządzanie ryzykiem powodziowym.

\section{ABSTRACT}

In the system of regulations concerning water management in the environmental law an essential task of economic importance is to create a unified system of flood risk management based on legal and economic methods. According to the assumption, such a system should eliminate the lack of preventions in flood protection and allow to introduce a unified systematic methodical approach in flood risk management. Establishing a common flood risk management system will one of the hardest tasks carried out in the nearest future. Its foundations are currently being created. Building such a system requires, in the first place, the development of a general legal model of flood protection that will form the basis of flood risk management. The model will be based on existing legal acts concerning water protection and it will draw on all the experience accumulated in the process of applying provisions concerning water management. This is also an issue of crucial importance for the effectiveness of environmental law instruments in the prevention of flooding effects.

\section{Keywords}

4/2014 ment.

System of regulations; environmental law; flood risk manage- 


\section{UWAGI WSTĘPNE}

Geneza zarządzania ryzykiem powodziowym jest tak długa jak historia samej inżynierii wodnej ${ }^{1}$. Władca starożytnego Egiptu Menes przegrodził niegdyś Nil błotem. Najprawdopodobniej użył do tego glinianych tarasów lub grobli po to, aby zatrzymać wodę na nisko położonym terenie, podczas corocznego cofania się powodzi. Faraonowie w Egipcie budowali kana$ł^{2}$. Według A.K. Biswas, prawdopodobnie największą pośrednią korzyść z rocznych wylewów Nilu stanowiło powstanie geometrii, której początki wiązały się z potrzebą przeprowadzenia pomiarów gruntów po każdym wylewie ${ }^{3}$. Egipcjanie dokonywali takich pomiarów, ponieważ wylewy Nilu powodowały rozmywanie działek ziemi ${ }^{4}$. Do najstarszych budowli ochrony przeciwpowodziowej należą wały ogradzające od rzeki miasta, osiedla, zakłady przemysłowe, trasy komunikacyjne oraz użytki rolne. Wały tego rodzaju były budowane w celu tworzenia systemu ochrony dolin rzek oraz w celu ochrony mniejszych obiektów. Długość wałów ochronnych może być bardzo zróżnicowana. Delta Wisły już w XIII w. posiadała obwałowania występujące na znacznych obszarach. Kazimierz Wielki zorganizował na dużą skalę wykonanie obwałowań w okolicy Krakowa. Według ugruntowanego przekonania, wielkie budownictwo wodne jest dowodem kultury i prężności narodu ${ }^{5}$. Obwałowania należą do najczęściej spotykanych i najprostszych sposobów ochrony przed powodzią $\mathrm{w}$ ramach tzw. ochrony biernej.

W literaturze dotyczącej zagadnień ochrony przeciwpowodziowej wyróżnia się ochronę przeciwpowodziową: bierną i czynną. Obwałowanie nazywane jest bronią obosieczną

1 Zob. szerzej: T. Szwed, T. Wróblewski, Zarys inżynierii wodnej, Kraków 1959, s. 40 i n.

2 M. Ogerman, Woda, przeł. R. Budzanowski, R. Romanowicz, Warszawa 1977, s. 87.

3 A.K. Biswas, Historia hydrologii, przeł. K. Chomicz-Jung, U. Zalewska-Okrutna, Warszawa 1978, s. 118.

4 Ibidem.

5 J. Lambor, Podstawy i zasady gospodarki wodnej, Warszawa 1965, s. 7. 
z uwagi na to, że wały często odcinają od rzeki rozległe tereny zalewowe. Z tego powodu zmniejsza się istniejąca dotąd naturalna retencja dolinowa. Konsekwencją tego jest powiększenie się przepływu wody i podwyższenie szczytu fali powodziowej. Występują często sytuacje, w których wały skutecznie zabezpieczające w ciągu setek lat dolny brzeg rzeki stają się za niskie w miarę coraz pełniejszego obwałowania rzeki powyżej ${ }^{6}$. Ochrona czynna (prewencyjna) sprowadza się do opanowania, lub co najmniej zmniejszenia, przyczyn powstania powodzi w wyniku różnych zabiegów w dorzeczu np. o charakterze agrotechnicznym i hydrotechnicznym. Do zabiegów agrotechnicznych zalicza się: właściwą uprawę roli, zalesienie zboczy oraz zabiegi przeciwerozyjne. Jest to „retencyjne przysposobienie dorzecza, prowadzące do zwiększenia wsiąkania wody $\mathrm{w}$ glebę, a tym samym zmiany odpływu powierzchniowego na gruntowy (spowolnienie i opóźnienie odpływu zasilającego rzeki)"”. Głównym zabiegiem hydrotechnicznym $\mathrm{w}$ ramach ochrony przeciwpowodziowej czynnej jest budowa zbiorników retencyjnych - przeciwpowodziowych (lub wielozadaniowych) najczęściej w górnych biegach rzek ${ }^{8}$. Umożliwiają one skuteczne czasowe zatrzymanie fali wezbraniowej (powodziowej). Środki stosowane w zarządzaniu ryzykiem powodziowym można podzielić na dwie grupy: 1) techniczne i 2) pozostałe. Zapobieganie katastrofalnym zatopieniom w wyniku przerwania wałów rodzi potrzebę budowania obwałowań wyższych oraz lepiej zabezpieczonych przed deformacjami filtracyjnymi. Często podnosi się, że „alternatywą jest pozostawienie terenów zalewowych niezabudowanych i nieobwałowanych" . Wydaje się, że takie rozwiązanie w wielu przypadkach jest jedynym sposobem na uniknięcie katastrofalnych zalań. Wskazuje się także na negatywne skutki budowy obwałowań. Należą do nich: pozbawienie terenów poza wałami wcześniej osadzonych na nich namułów, niekorzystny wpływ na

6 A. Tuszko, Gospodarka wodna, Warszawa 1967, s. 271.

7 Z. Mikulski, Gospodarka wodna, Warszawa 1998, s. 79.

8 Ibidem.

9 J. Rotko, Dział V. Ochrona przed powodziq oraz susza, [w:] J. Rotko, Prawo wodne. Komentarz, Wrocław 2002, s. 234. 
reżim rzeki, podwyższenie stanu wody, utrata części retencji dolinowej oraz katastrofalne straty po przerwaniu wału ${ }^{10}$.

Zarządzanie ryzykiem powodziowym jest jednym z głównych czynników decydujących o kształcie działań międzynarodowych na rzecz ochrony przed powodzią. Zagrożenia związane występowaniem powodzi mogą wywołać istotne zakłócenia w poziomie globalnego bezpieczeństwa ekologicznego. Zdaniem K. Karpus, „Problematyka ochrony przed powodzią jest więc $\mathrm{w}$ prawie międzynarodowym publicznym już zarysowana, w pracach na forum międzynarodowym dostrzegalny jest też wysiłek rozwijania koncepcji zintegrowanego zarządzania ryzykiem powodziowym, z naciskiem na aspekt współpracy państw wód międzynarodowych. Oprócz wątków zapobiegania powodzi, dostrzegane są również kwestie dalsze, to jest współpraca w razie wystąpienia tego zjawiska"11.

\section{ZARZĄDZANIE RYZYKIEM POWODZIOWYM W PRAWIE WSPÓLNOTOWYM}

W systemie regulacji dotyczących gospodarki wodnej w prawie wspólnotowym ważnym zadaniem o znaczeniu ogólnogospodarczym jest utworzenie jednolitego systemu zarządzania ryzykiem powodziowym opartego na metodach prawno-ekonomicznych. System taki według założeń prawa i polityki UE powinien zlikwidować brak prewencji w ochronie przed powodzią i pozwolić na wprowadzenie jednolitego systemowego podejścia metodycznego $\mathrm{w}$ zarządzaniu ryzykiem powodziowym. Utworzenie wspólnego systemu zarządzania ryzykiem powodziowym w UE będzie jednym z trudniejszych zadań realizowanych w najbliższej przyszłości. Obecnie stworzone zostały jego podwaliny. Zbudowanie takiego systemu wymaga w pierwszej kolejności opracowania ogólnego modelu

10 Ibidem.

11 K. Karpus, Ochrona przed powodziq i susza, [w:] B. Rakoczy (red.), Wybrane problemy prawa wodnego, LEX 2013, nr 181168. 
prawnego ochrony przed powodzią stanowiącego podstawę zarządzania ryzykiem powodziowym. Model taki powinien opierać się na obowiązujących już aktach prawnych dotyczących zarządzania wodami oraz musi czerpać z całości doświadczeń nagromadzonych $\mathrm{w}$ procesie stosowania przepisów regulujących gospodarkę wodną w UE. Problematykę zarządzania ryzykiem powodziowym w prawie wspólnotowym regulują przepisy dyrektywy 2007/60/WE Parlamentu Europejskiego i Rady z 23 października 2007 r. w sprawie oceny ryzyka powodziowego i zarządzania nim ${ }^{12}$. Zgodnie $\mathrm{z}$ ww. dyrektywą cele dotyczące zarządzania ryzykiem powodziowym powinny być określone przez państwa członkowskie i muszą się opierać na warunkach lokalnych i regionalnych. Jednym z podstawowych instrumentów zarządzania ryzykiem powodziowym są plany zarządzania ryzykiem powodziowym. Plany te powinny uwzględniać triadę działań obejmujących: zapobieganie, ochronę i przygotowanie. $\mathrm{W}$ tym celu przewiduje się $\mathrm{w}$ planach uwzględnienie w większym stopniu utrzymywania i/lub odnowy tarasów rozlewowych, a także środków zapobiegających szkodom związanym ze zdrowiem ludzkim, środowiskiem, dziedzictwem kulturowym i działalnością gospodarczą oraz minimalizujących tego rodzaju szkody. Państwa członkowskie powinny opierać swoje oceny, mapy i plany związane z zarządzaniem ryzykiem powodziowym na odpowiednich „najlepszych praktykach” i „najlepszych dostępnych technologiach" niepowodujących nadmiernych kosztów.

Celem podstawowym wynikający $\mathrm{z}$ treści dyrektywy 2007/60/WE jest ustanowienie ram dla oceny ryzyka powodziowego i zarządzania nim, w celu ograniczania negatywnych konsekwencji dla zdrowia ludzkiego, środowiska, dziedzictwa kulturowego oraz działalności gospodarczej, związanych z powodziami na terytorium Wspólnoty. Państwa członkowskie były zobowiązane także do dokonania wstępnej oceny ryzyka powodziowego do dnia 22 grudnia 2011 r. w odniesieniu do każdego obszaru dorzecza lub jednostki zarządzającej, lub fragmentu międzynarodowego dorzecza, któ- 
re są położone na ich terytorium. Na podstawie wstępnej oceny ryzyka powodziowego, państwa członkowskie dla każdego obszaru dorzecza lub jednostki zarządzającej lub fragmentu międzynarodowego obszaru dorzecza, które są położone na ich terytorium, powinny określić takie obszary, na których stwierdzają istnienie dużego ryzyka powodziowego lub jego wystąpienie jest prawdopodobne. Dyrektywa 2007/60/ /WE przewiduje ponadto obowiązek przygotowania przez państwa członkowskie na poziomie obszaru dorzecza lub jednostki zarządzającej map zagrożenia powodziowego i map ryzyka powodziowego w najbardziej odpowiedniej skali. Mapy zagrożenia powodziowego jako jeden $\mathrm{z}$ instrumentów zarządzania powinny obejmować obszary geograficzne, na których może wystąpić powódź. Mapy ryzyka powodziowego przedstawiają potencjalnie negatywne skutki związane z powodzią. Na podstawie map zagrożenia powodziowego państwa członkowskie opracowują plany zarządzania ryzykiem powodziowym, skoordynowane na poziomie obszaru dorzecza lub jednostki zarządzającej.

W Komunikacie Komisji dla Rady, Parlamentu Europejskiego, Europejskiego Komitetu Ekonomiczno-Społecznego i Komitetów Regionów „Zarządzanie zagrożeniem powodziowym. Zapobieganie powodziom, ochrona przeciwpowodziowa i ograniczenie skutków powodzi z 12 lipca 2004 r. ${ }^{13}$ ", określone zostały działania obejmujące zarządzanie zagrożeniem powodziowym. Mają one na celu zmniejszenie prawdopodobieństwa i/lub wpływu powodzi. Najbardziej skutecznym podejściem jest podejmowanie działań $\mathrm{w}$ ramach programów zarządzania zagrożeniem powodziowym. Obejmują one następujące elementy: 1) zapobieganie powstawaniu szkód wywołanych powodziami poprzez rezygnację z budowy domów mieszkalnych i obiektów przemysłowych obecnie i w przyszłości na terenach zagrożonych powodzią; poprzez dostosowywanie obiektów, które powstaną w przyszłości do zagrożenia powodziowego; oraz przez wspieranie właściwego zagospodarowania terenu, praktyk rolniczych i leśnych; 2) podejmowanie środków, strukturalnych i niestruk-

13 KOM (2004) 472 z 12.07. 2004 r. 
turalnych, w celu zmniejszenia prawdopodobieństwa wystąpienia powodzi i/lub wpływu powodzi w określonych miejscach; 3) informowanie ludności o zagrożeniu powodziowym oraz o zasadach postępowania w wypadku powodzi; 4) opracowanie planów awaryjnych na wypadek wystąpienia powodzi; 5) przywracanie normalnych warunków i wyciąganie wniosków: powracanie możliwie najszybciej do normalnych warunków i łagodzenie skutków społecznych i gospodarczych w wypadku osób dotkniętych powodzią.

\section{CHARAKTERYSTYKA POJĘCIA PRAWNEGO „RYZYKO POWODZIOWE” W USTAWIE PRAWO WODNE}

W badaniu ogólnym pojęcia prawne charakteryzujące ryzyko powodziowe możemy podzielić na teoretyczne i praktyczne. Treść pojęć teoretycznych, takich jak np. „zrównoważony rozwój”, „ochrona środowiska”, została określona przez teorię, która powiązała je z terminami praktycznymi takimi jak np.: „budowle przeciwpowodziowe” czy „cele zarządzania ryzykiem powodziowym”. Teksty prawne składają się z pojęć teoretycznych oraz praktycznych. Zwłaszcza te ostatnie podlegają weryfikacji i są wykorzystywane dla potwierdzenia funkcji pojęć teoretycznych. Wobec często podnoszonej wieloznaczności treści nadawanej podobnym czy nawet tym samym pojęciom występującym w aktach normatywnych dotyczących zarządzania zasobami wodnymi celowe wydaje się przynajmniej wstępne usystematyzowanie znaczenia stosowanych pojęć. Pozwoli to w dalszej kolejności na szerszą i bardziej szczegółową analizę prewencyjnego charakteru zarządzania ryzykiem powodziowym w ustawie p.w. Według K. Opałka, „Z problemami wieloznaczności i płynności zakresów terminów mamy nagminnie do czynienia w rozważaniach na temat dyscyplin zaliczanych do prawoznawstwa przy próbach określenia ich wzajemnych sto- 
sunków"14. Należy podkreślić, że wieloznaczność jest znamienna dla większości pojęć prawnych wchodzących w skład systemu prawa ochrony środowiska. Stwarza to oczywiście określone problemy w posługiwaniu się całą siatką pojęciową związaną z zarządzaniem zasobami środowiska. Między poznaniem znaczenia pojęć prawnych i kształtującą się na jego podstawie wiedzą a praktyką ich stosowania istnieje wzajemne sprzężenie zwrotne. $\mathrm{Z}$ jednej strony poznanie i interpretowanie pojęć wyrasta głównie z potrzeb praktycznego ich stosowania i dopiero na pewnym etapie rozwoju danej dyscypliny prawa wydziela się w osobną część systemu prawa. Z drugiej strony poznawanie pojęć i będąca jego efektem wiedza stają się nie tylko warunkiem, lecz także $\mathrm{w}$ pewnym sensie elementem struktury prawa i jego interpretacji.

Zagadnienia dotyczące zarządzania ryzykiem powodziowym w ustawie z dnia 18 lipca 2001 r. Prawo wodne (p.w.) regulują przepisy działu VA zatytułowanego „Ochrona przed powodzią" (art. 88a-88q). Ochrona przed powodzią generalnie realizuje określone w normach prawnych funkcje zarządzania ryzykiem powodziowym ${ }^{15}$. Zarządzanie występuje $\mathrm{w}$ dwóch zasadniczych formach: sterowania, czyli wyznaczenia celów i norm, powodowania ich realizacji, oraz konstruowania układów regulacji ${ }^{16}$. B. Poskrobko podnosi, że zarządzanie środowiskiem jest nauką i działalnością praktyczną, zajmującą się projektowaniem, wdrażaniem i koordynowaniem procesów gospodarowania środowiskiem. Jego zdaniem, procesy użytkowania, ochrony i kształtowania środowiska przebiegają w sferze społecznej, gospodarczej i przyrodniczej ${ }^{17}$.

14 K. Opałek, Filozofia prawa a filozofia społeczna, [w:] H. Groszyk, J. Malarczyk, A. Pieniążek, W. Skrzydło, W. Śladkowski (red.), Problemy teorii i filozofii prawa, Lublin 1985, s. 193.

15 Por. J. Zieleniewski, Organizacja i zarządzanie, Warszawa 1969, s. 477.

16 A. K. Koźmiński, K. Obłój, Strategie zarządzania, [w:] A. K. Koźmiński (red.), Współczesna koncepcje zarządzania, Warszawa 1985, s. 359.

17 B. Poskrobko, Nowe aspekty koncepcji systemu zarządzania środowiskiem, [w:] J. Ejdys, A. Matuszak-Flejszman (red.), Od integracji systemów zarządzania do TQM, Poznań 2003, s. 55. 
Zarządzanie ryzykiem powodziowym jest łączone $\mathrm{z}$ podejmowaniem decyzji związanych z ustaleniem, który z możliwych i realnych wariantów kombinacji celów ze środkami przyniesie największe korzyści dla obszarów narażonych na niebezpieczeństwo powodzi. Obszarami narażonymi na niebezpieczeństwo powodzi są określone we wstępnej ocenie ryzyka powodziowego obszary, na których istnieje znaczące ryzyko powodzi lub jest prawdopodobne wystąpienie znaczącego ryzyka powodzi (art. 9 ust. 6b p.w.). W teoretycznym ujęciu ryzyko można mierzyć wyłącznie za pomocą rachunku prawdopodobieństwa. W literaturze przyjmuje się, że „Przez ryzyko normalne należy rozumieć niepewność w działaniu możliwą do przewidzenia za pomocą rachunku prawdopodobieństwa (metoda matematyczna) albo za pomocą prawdopodobieństwa zdarzeń określanych szacunkowo na podstawie posiadanych informacji, aktualnego stanu wiedzy, doświadczenia i intuicji (metoda prakseologiczna)"18.

Ryzyko powodziowe oznacza kombinację prawdopodobieństwa wystąpienia powodzi i potencjalnych negatywnych skutków powodzi dla życia i zdrowia ludzi, środowiska, dziedzictwa kulturowego oraz działalności gospodarczej. W praktyce prawdopodobieństwo zdarzeń jest podstawą przy podejmowaniu decyzji. Stopień niezawodności takiej decyzji zależy od stopnia wykorzystania czynnika intuicji. Zdaniem B. Nietykszy, im mniejszy jest stopień zaangażowania czynnika intuicji, tym większy jest stopień niezawodności w uzyskaniu spodziewanego efektu. Zdaniem Europejskiego Trybunału Praw Człowieka, „Należy wskazać na istnienie warunków technicznych, z których jasno wynikało, że obszar dookoła przedmiotowego zbiornika retencyjnego nie powinien być zamieszkany, jeżeli nie zostaną podjęte określone środki zapobiegawcze. [...] Od organów władzy należało zatem oczekiwać albo zastosowania odpowiednich ograniczeń w sferze zagospodarowania przestrzennego i uniemożliwienia osadnictwa na przedmiotowym terenie, albo podjęcia skutecznych środków w celu ochrony

18 B. Nietyksza, Zasady kompensacji szkód z tytułu ryzyka, Warszawa 1971, s. 24-25. 
przeciwpowodziowej tego obszaru przed wydaniem pierwszego zezwolenia na budowę"19.

Zarządzanie ryzykiem powodziowym jest jednym z głównych instrumentów ochrony przed powodzią. Zgodnie $\mathrm{z}$ art. 88a ust. 4 p.w., ochronę przed powodzią realizuje się, uwzględniając wszystkie elementy zarządzania ryzykiem powodziowym, w szczególności zapobieganie, ochronę, stan należytego przygotowania i reagowanie $\mathrm{w}$ przypadku wystąpienia powodzi, usuwanie skutków powodzi, odbudowę i wyciąganie wniosków w celu ograniczania potencjalnych negatywnych skutków powodzi dla zdrowia ludzi, środowiska, dziedzictwa kulturowego oraz działalności gospodarczej. Wstępną ocenę ryzyka powodziowego przygotowuje Prezes Krajowego Zarządu Gospodarki Wodnej. Wstępną ocenę od strony morza, w tym morskich wód wewnętrznych, przygotowuje minister właściwy do spraw gospodarki morskiej i przekazuje Prezesowi Krajowego Zarządu Gospodarki Wodnej, nie później niż na 6 miesięcy przed terminem przygotowania wstępnej oceny ryzyka powodziowego. Wstępna ocena ryzyka powodziowego od strony morza, w tym morskich wód wewnętrznych, stanowi integralny element wstępnej oceny ryzyka powodziowego przygotowanej przez Prezesa Krajowego Zarządu Gospodarki Wodnej. Prezes Krajowego Zarządu Gospodarki Wodnej przekazuje projekt wstępnej oceny ryzyka powodziowego do zaopiniowania właściwym wojewodom oraz marszałkom województw. Właściwi wojewodowie oraz marszałkowie województw opiniują projekt wstępnej oceny ryzyka powodziowego.

Dla obszarów narażonych na niebezpieczeństwo powodzi wskazanych we wstępnej ocenie ryzyka powodziowego sporządza się mapy zagrożenia powodziowego. Mapy zagrożenia powodziowego oraz mapy ryzyka powodziowego sporządza Prezes Krajowego Zarządu Gospodarki Wodnej. Mapy zagrożenia powodziowego oraz mapy ryzyka powodziowego od strony morza, w tym morskich wód wewnętrznych, przygotowują dyrektorzy urzędów morskich i przekazują Prezesowi Krajowego

19 Wyrok Europejskiego Trybunału Praw Człowieka z 28 lutego 2012 r. sygn. akt 17423/05, LEX nr 1117409. 
Zarządu Gospodarki Wodnej nie później niż na 6 miesięcy przed terminem przygotowania map zagrożenia powodziowego oraz map ryzyka powodziowego. Mapy zagrożenia powodziowego oraz mapy ryzyka powodziowego od strony morza, w tym morskich wód wewnętrznych, stanowią integralny element map zagrożenia powodziowego oraz map ryzyka powodziowego.

Plany zarządzania ryzykiem powodziowym dla obszarów dorzeczy oraz dla regionów wodnych przygotowuje się na podstawie map zagrożenia powodziowego oraz map ryzyka powodziowego. Plany zarządzania ryzykiem powodziowym dla obszarów dorzeczy przygotowuje Prezes Krajowego Zarządu Gospodarki Wodnej w uzgodnieniu z ministrem właściwym do spraw gospodarki wodnej. Projekty planów zarządzania ryzykiem powodziowym dla regionów wodnych przygotowują dyrektorzy regionalnych zarządów gospodarki wodnej i przekazują Prezesowi Krajowego Zarządu Gospodarki Wodnej nie później niż na 15 miesięcy przed terminem przygotowania planów zarządzania ryzykiem powodziowym. Plany zarządzania ryzykiem powodziowym dla regionów wodnych stanowią integralny element planów zarządzania ryzykiem powodziowym. J. Rotko plany zarządzania ryzykiem powodziowym zalicza do grupy „dokumentów planistycznych”, którymi posługuje się ustawa p.w., obejmujących plany i programy wykazujące znaczne zróżnicowanie formalne i materialne. Obok ww. planów zarządzania ryzykiem powodziowym autor ten zalicza do nich także: program wodno-środowiskowy kraju oraz plany gospodarowania wodami, plany przeciwdziałania skutkom suszy na obszarze dorzecza, warunki korzystania z wód regionu wodnego oraz sporządzane w miarę potrzeby warunki korzystania z wód ${ }^{20}$. W orzecznictwie wyrażono słuszny pogląd, według którego dokonując ustaleń w planie miejscowym, gmina zobowiązana jest uwzględnić okoliczność, że działka znajduje się na terenie zalewowym. Mając zatem na uwadze konieczność zapewnienia ochrony życia i mienia, gmina zobowiązana jest do dokonania takich ustaleń w planie miejscowym, które pozwoli-

20 J. Rotko, Ramowa dyrektywa wodna - analiza prawna, Poznań 2013, s. $230-231$. 
łyby na pełną realizację tego obowiązku, który sprowadza się do ograniczenia zabudowy na działkach położonych na terenach zalewowych ${ }^{21}$.

Proces planowania $\mathrm{w}$ zarządzaniu ryzykiem powodziowym nakierowany jest na wywieranie wpływu organów tworzących plany na określone sfery życia ludzkiego, które objęte są procesem planowania ${ }^{22}$. W ocenie K. Strzyczkowskiego, „W obrębie planowania administracyjnego podstawowe znaczenie jest przypisywane zasadom i instrumentacji prawnej $\mathrm{w}$ takich kwestiach, jak: sfera wolności od planowania, zakresu uznania planowego, kontroli legalności i gwarancji planów"23. M. Królikowska-Olczak uznaje natomiast za słuszny pogląd akcentujący istotę planowania jako metody koordynacji celów i środków, synchronizacji działań i środków do realizacji określonych celów ${ }^{24}$. Według J. Gościńskiego, „[...] mamy wprawdzie zbiory zasad i wytycznych planowania oraz sporządzania planów, nie ma natomiast ani aksjomatycznej teorii planowania, ani też poprawnych naukowo definicji planu i procesu planowania"25. Autor ten postrzega plan jako dokument zatwierdzony „przez osobę lub zespół do tego upoważniony, będący zatem aktem planistycznym uzyskanym jako efekt procesu planowania. Jest to zatem decyzja określająca cele, zadania i sposób ich realizacji w ściśle określonym czasie, ustalająca rezultat końcowy działań koniecznych do wykonania zadania w sposób efektywny. Istota rzeczy polega na tym, że jest to decyzja, którą można wyegzekwować, określając przyszły pożądany stan systemu będącego przedmiotem planowania oraz sposób osiągnięcia zamierzone-

21 Zob. wyrok NSA w Warszawie z 10 lipca 2012 r., syg. akt II OSK 1110/12, LEX nr 1225719.

22 K. Strzyczkowski, Administracyjnoprawne instytucje planowania, Warszawa 1985, s. 13.

23 Tamże, s. 15.

24 M. Królikowska-Olczak, Problemy prawne zarządzania działalnościa gospodarcza prowadzona przez kapitalistyczne podmioty gospodarcze w państwach socjalistycznych na przykładzie Polski, Łódź 1990, s. 101.

25 J. Gościński, Zarys teorii sterowania ekonomicznego, Warszawa 1977, s. 243. 
go stanu na koniec okresu objętego planem”26. J. Kryński określa plan jako „zbiór decyzji planistycznych dotyczących gospodarki narodowej”27. R. L. Ackoff twierdzi, że „Plan jest zapisem złożonego zbioru wzajemnie na siebie oddziałujących decyzji" ${ }^{28}$. Z definicji tych wynika, że plan najczęściej odzwierciedla pożądany stan rzeczy w danej dziedzinie, którego realizacja nie jest pewna i jest związana z ryzykiem wystąpienia okoliczności, które nie muszą być objęte planem.

W gospodarce wodnej obowiązek przygotowania zarządzania ryzykiem powodziowym jest związany z niepewnością pojawienia się zagrożeń $\mathrm{w}$ związku $\mathrm{z}$ wystąpieniem powodzi. J. Mothes, omawiając sposoby podejmowania decyzji, analizuje pojęcie sytuacji niepewnej, która występuje, gdy wpływ na skutki mają parametry niepewne, na temat których nie ma żadnych informacji o możliwych ich zmianach. Znając te zależności występowania sytuacji niepewnej, powinniśmy określić cele działalności planowanej w zarządzaniu ryzykiem powodziowym ${ }^{29}$. F. Piontek, S. Dziadek, J. Kusztal, Z. Łabno uważają, że zagadnienia ochrony środowiska reprezentowane są $\mathrm{w}$ wielu planach tematycznych. Ich zdaniem, rzeczywista procedura planowania ochrony środowiska jest bardzo trudna do opisania i oceny, ponieważ wymaga uchwycenia wszystkich nieformalnych związków, które występują w procesie przygotowania, podejmowania i przekazywania decyzji. Struktura formalna procesu planowania nie zawsze sprzyja też podejmowaniu działań racjonalnych w zakresie reprodukcji i wykorzystania środowiska przyrodniczego. Jeżeli procedura formalna nie zapewnia racjonalności działania, może to między innymi powodować odchylenia między procedurą rzeczywistą i formalną i świadczyć o braku

26 Ibidem, s. 246.

27 J. Kryński, Planowanie rozwoju społeczno-gospodarczego, Warszawa 1976, s. 16.

28 R.L. Ackoff, Zasady planowania $w$ korporacjach, przeł. A. Szeworski, Warszawa 1973, s. 25.

29 Por. J. Mothes, Sytuacje niepewne a podejmowanie decyzji w przemyśle, przeł. S. Budkowski, Warszawa 1972, s. 11. 
skuteczności obowiązujących aktów prawnych ${ }^{30}$. J. Łętowski słusznie podnosi, że „Polityczno-ekonomiczne ewolucje pojęcia planu powodują, że samo określenie »plan« dla prawnika niewiele znaczy. Plan może być planem normą lub też planem informacją; jeśli w pewnej sytuacji uznamy go za normę, odnosić się będzie z reguły tylko do konkretnej sytuacji i niczego nie przesądzi na przyszłość. [...] Słowem, prawna problematyka planowania wiąże się dzisiaj z wielkimi komplikacjami i mnóstwem niejasności; nauka czyni pewne wysiłki, aby wprowadzić tu pewien stały porządek, trudno jednak mówić, aby dzisiaj odnosiła na tym polu szczególne sukcesy"31.

Cele wynikające z planów zarządzania ryzykiem powodziowym są jednocześnie celami prawa ochrony środowiska i polityki ekologicznej. Zadania administracji związane z zarządzaniem ryzkiem powodziowym są natomiast ich skonkretyzowaniem w treści planów. Przy wyznaczaniu celów i zadań planów należy uwzględniać w miarę potrzeb i możliwości wymagania najlepszych dostępnych technik i technologii. Właściwością wszystkich założeń planistycznych dotyczących zarządzania ryzykiem powodziowym jest przeświadczenie nie tylko o możliwości przewidywania przyszłości, ale przede wszystkim o możliwości jej kształtowania w sposób odpowiadający organom administracji planującym działania zapobiegające powodziom ${ }^{32}$. Ważnymi elementami zarządzania ryzykiem powodziowym są informacje i dane. Jak twierdzi A. K. Koźmiński, „podejmowanie decyzji jest procesem, który sprowadza się do zbierania i przetwarzania informacji o przyszłym działaniu". W procesie tym jego zdaniem można wyodrębnić trzy główne fazy. Pierwszą fazę można nazwać przygotowawczą (informacyjną). Sprowadza się ona do zbierania informacji na temat przyszłego działania, warunków

30 F. Piontek, S. Dziadek, J. Kusztal, Z. Łabno, Planowanie procesów ochrony i kształtowania środowiska, [w:] S. Jarzębski (red.), Organizacja i funkcjonowanie procesów ochrony środowiska na szczeblu centralnym i regionalnym, Wrocław-Warszawa-Karków-Gdańsk 1980, s. 79.

31 J. Łętowski, Administracja, prawo, orzecznictwo sądowe, Wrocław-Warszawa-Karków-Gdańsk-Łódź 1985, s. 164.

32 Por. Z. Kowalewski, Nauka a planowanie jej rozwoju, Wrocław-Warszawa-Kraków 1967, s. 105. 
w jakich będzie się ono odbywało, środków pozostawionych do dyspozycji. W tej fazie następuje również przetwarzanie informacji z punktu widzenia zamiaru wydania przyszłej decyzji. Formułowanie wariantów decyzji wymaga dostępu do informacji. W drugiej fazie dokonuje się właściwego wyboru. Trzecia faza obejmuje realizacje wybranego wariantu działania. Weryfikacja decyzji może zdaniem tego autora, oznaczać powrót do faz poprzednich poprzez uzyskiwanie nowych informacji i ponowne ich przetwarzanie ${ }^{33}$. Informacja jego zdaniem zawiera wszystko to, co oddziałuje na człowieka i jego zmysły i jest przez człowieka identyfikowane. W ujęciu węższym informacja jest treścią, która jest przekazywana w czasie od danego członu nadawczego jako twórcy informacji do członu odbiorczego ${ }^{34}$. M. Król podkreśla, że niepomierny wzrost ilości informacji w kontekście określonych możliwości technicznych stworzył konieczność wypracowania szybkich i efektywnych metod dostępu i odtwarzania informacji zgromadzonych z bazach danych ${ }^{35}$.

Organy administracji rządowej i samorządowej są zobowiązane do nieodpłatnego przekazywania danych niezbędnych do przygotowania wstępnej oceny ryzyka powodziowego, sporządzenia map zagrożenia powodziowego i map ryzyka powodziowego oraz przygotowania planów zarządzania ryzykiem powodziowym organom przygotowującym i sporządzającym te dokumenty. Ochronę ludzi i mienia przed powodzią realizuje się w szczególności przez: 1) kształtowanie zagospodarowania przestrzennego dolin rzecznych lub terenów zalewowych; 2) racjonalne retencjonowanie wód oraz użytkowanie budowli przeciwpowodziowych, a także sterowanie przepływami wód; 3) zapewnienie funkcjonowania systemu wczesnego ostrzegania przed niebezpiecznymi zjawiskami zachodzącymi w atmosferze i hydrosferze oraz prognozowanie powodzi; 4) zachowanie, tworzenie i odtwarzanie systemów retencji wód; 5) budowę,

33 A. K. Koźmiński, Wstęp, [w:] A. K. Koźmiński (red.), Decyzje. Analiza systemowa organizacji, Warszawa 1979, s. 6.

34 Ibidem.

35 M. Król, Wybrane zagadnienia informatyki prawniczej, [w:] J. Wróblewski (red.), Wstęp do informatyki prawniczej, Warszawa 1985, s. 103. 
rozbudowę i utrzymywanie budowli przeciwpowodziowych; 6) prowadzenie akcji lodołamania.

Na obszarach szczególnego zagrożenia powodzią obowiązuje zakaz wykonywania robót oraz czynności utrudniających ochronę przed powodzią lub zwiększających zagrożenie powodziowe, w tym: 1) wykonywania urządzeń wodnych oraz budowy innych obiektów budowlanych, z wyjątkiem dróg rowerowych; 2) sadzenia drzew lub krzewów, z wyjątkiem plantacji wiklinowych na potrzeby regulacji wód oraz roślinności stanowiącej element zabudowy biologicznej dolin rzecznych lub służącej do wzmacniania brzegów, obwałowań lub odsypisk; 3) zmiany ukształtowania terenu, składowania materiałów oraz wykonywania innych robót, z wyjątkiem robót związanych z regulacją lub utrzymywaniem wód oraz brzegu morskiego, budową, przebudową lub remontem drogi rowerowej, a także utrzymywaniem, odbudową, rozbudową lub przebudową wałów przeciwpowodziowych wraz z obiektami związanymi z nimi funkcjonalnie oraz czynności związanych z wyznaczaniem szlaku turystycznego pieszego lub rowerowego (art. 881 ust. 1). Dla terenów, dla których nie określono obszarów narażonych na niebezpieczeństwo powodzi, właściwy dyrektor regionalnego zarządu gospodarki wodnej może, w drodze aktu prawa miejscowego, wprowadzić zakazy, o których mowa w art. 40 ust. 1 pkt 3, kierując się potrzebą ochrony wód, lub zakazy, o których mowa w art. 881 ust. 1, ze względów na bezpieczeństwo ludzi i mienia.

\section{CELE NORMATYWNE ZARZADZANIA RYZYKIEM POWODZIOWYM}

Jedną $\mathrm{z}$ istotnych cech charakterystycznych regulacji prawnej dotyczącej zarządzania ryzykiem powodziowym są cele, które wyznaczył prawodawca. Z tego powodu w badaniach systemu prawa ochrony środowiska doktryna najczęściej skupia swoją uwagę na instrumentach prawnych realizujących poszczególne cele. Przez cele zarządzania ryzykiem powodzio- 
wym ustawodawca rozumie ograniczenie potencjalnych negatywnych skutków powodzi dla życia i zdrowia ludzi, środowiska, dziedzictwa kulturowego oraz działalności gospodarczej (art. 9 ust. 1b p.w.). W zarządzaniu ryzykiem powodziowym szczególną rolę odgrywa cel w postaci ograniczenia potencjalnych negatywnych skutków powodzi. Powinien on warunkować dobrą realizację wszystkich pozostałych celów zarządzania ryzykiem powodziowym, pozostających w zgodzie z wymaganiami prawa ochrony środowiska i gospodarki wodnej. Istnieje w związku z tym konieczność właściwej interpretacji wszystkich celów zarządzania ryzykiem powodziowym zgodnie z zasadą racjonalności. J. Supernat, analizując zasadę racjonalności w ramach instrumentów działania administracji publicznej, stwierdza, że „Zasada ta nakazuje oceniać wybór instrumentów działania przez administrację publiczną z punktu widzenia procedury dokonania tego wyboru"36. Jego zdaniem, warunkiem uznania wyboru instrumentu działania administracji publicznej za racjonalny jest dokonanie go przez podmiot administracyjny w trakcie procedury decyzyjnej, która składa się z następujących etapów: 1) analiza zadania, które ma zostać zrealizowane, 2) zidentyfikowanie wszystkich dopuszczalnych instrumentów pozwalających je zrealizować, 3) ustalenie możliwych konsekwencji zastosowania każdego z instrumentów, 4) wybór instrumentu, który daje największą pewność realizacji zadania (w największym zakresie, z minimalnym wysiłkiem itd.) ${ }^{37}$.

Odwołując się do celów, możemy również badać funkcje regulacji prawnych. Przepisy prawne dotyczące ochrony przed powodzią tworzą także system wielopoziomowych i dynamicznych powiązań pomiędzy instrumentami prawnymi realizującymi cele i wartości prawa ochrony wód. Obecnie pojawia się konieczność wyodrębnienia poziomów pośrednich, jak np. poziom regulacji prawnych dotyczących gospodarki wodnej i ochrony przed powodzią. Są to rozwijające się dynamicznie podsystemy prawa ochrony środowiska realizujące przy pomo-

36 J. Supernat, Instrumenty działania administracji publicznej. Studium z nauki administracji, Kolonia Limited 2003, s. 132.

37 Ibidem. 
cy instrumentów prawnych jego podstawowe cele. Współczesne metody badania płaszczyzn stosowania prawa ochrony środowiska wykazują jasno, że nie da się ich prawidłowo stosować bez szerszego poznania celów poszczególnych regulacji prawnych. Gdy ujmujemy wszystkie normy prawne chroniące środowisko w powiązaniu ze sobą, wówczas okazuje się, że to, co jednostkowe, i to, co ogólne, jest w nich powiązane przy pomocy celów prawa ochrony środowiska. Są one także elementem powtarzalnym $\mathrm{w}$ procesie stosowania prawa. $\mathrm{Z}$ tych powodów wydaje się uprawnione wyodrębnianie za pomocą abstrakcji naukowej poszczególnych celów instrumentów prawnych. Umożliwia to głębszą analizę części składowych systemu prawa w ich wzajemnym powiązaniu zadaniami adresatów norm prawnych. Najważniejszym i zawsze naczelnym czynnikiem procesu decyzyjnego jest otrzymane do wykonania zadanie. Jest to pierwszy element każdego procesu decyzyjnego i jednocześnie cel dalszego działania, wynikającego z zadania. Według M. Maneli, „działalność władzy państwowej jest w tym sensie celowa, że każde jej działanie wychodzi z określonych motywów i skierowane jest na urzeczywistnienie określonych celów (zadań)"38.

Zadania publiczne $\mathrm{w}$ zarządzaniu ryzykiem powodziowym, zapewniające realizację integrujących zadań systemowych w gospodarce wodnej, wykonywane są głównie przez organy administracji rządowej i samorządowej. Zdaniem T. Skonecznego, „zadanie administracji państwowej to preskryptywny wyraz tego, co ma być w rzeczywistości wykonane dla urzeczywistnienia celu państwa przez jego administrację, za pomocą określonych środków i działań". Autor ten twierdzi, że do zakwalifikowania danego zadania jako zadania administracji państwowej konieczne jest spełnienie następujących warunków: 1) istnienie celu państwa, którego urzeczywistnieniu ma służyć to zadanie; 2) uznanie, że administracja państwowa jest podmiotem odpowiedzialnym za wykonanie zadania; 3) stworzenie środków, które mają służyć realizacji zadania (w znaczeniu preskryptywnym) oraz 4) zaznaczenie, że w celu wykonania określonego zadania podejmowane są faktycznie dane środki

38 M. Maneli, O funkcjach państwa, Warszawa 1963, s. 55. 
lub działania (w znaczeniu deskryptywnym) ${ }^{39}$. Dla potwierdzenia bytu zadania konieczne jest istnienie dwóch składników w postaci: 1) formalnego wyznaczenia oraz 2) faktycznego wykonania zadania. Według M. Stahl, „określenie zadania publicznego, celu publicznego, a szerzej interesu publicznego, jest zmienne w czasie i przestrzeni, zależy od określonego kontekstu prawnego, politycznego, społecznego, przyjmowanego systemu wartości" ${ }^{40}$. Warto w tym miejscu wskazać na znaczenie dwóch istotnych pojęć: „cel” i „wartość”. Cel obejmuje to, do czego dążą władze publiczne realizujące dane zadanie. Na przykład, celem organów administracji w ochronie przed powodzią może być skuteczne zarządzanie ryzykiem powodziowym. Władze publiczne mogą podporządkowywać swoje interesy temu celowi. Pojęcie „wartość” obejmuje uznanie przez społeczeństwo lub organy władzy publicznej określonych właściwości jakiegoś zjawiska, które posiadają pozytywne znaczenie dla danego podmiotu, który ocenia te wartości. Taką wartością może być np. bezpieczeństwo powodziowe.

Szczególną różnorodność problematyki badawczej związanej z celami ochrony przed powodzią można dostrzec w zarządzaniu ryzykiem powodziowym. Wiele celów na różnych płaszczyznach działania przepisów p.w. przypisać można także zapobieganiu skutkom powodzi. Wśród licznych, które można odnaleźć na pierwszym planie, występuje generalny cel prewencyjny w zarządzaniu ryzykiem powodziowym. Funkcja prewencyjna prawa ochrony środowiska jest obecnie nierozdzielnie związana z szeregiem instrumentów prawnych zarządzania zasobami środowiska. Badanie tej funkcji w regulacjach prawnych dotyczących ochrony przed powodzią nie jest dla praktyki tworzenia i stosowania prawa sprawą obojętną. W opinii Europejskiego Komitetu Ekonomiczno-Społecznego w sprawie

39 T. Skoczny, O niektórych problemach teorii zadań administracji państwowej, OMT 1985/11-12, s. 3.

40 M. Stahl, Cele publiczne i zadania publiczne, [w:] J. Zimmermann (red.), Koncepcja systemu prawa administracyjnego: Zjazd Katedr Prawa Administracyjnego i Postępowania Administracyjnego, Zakopane, 24-27 września 2006 r., Warszawa 2007, s. 95. 
komunikatu Komisji dla Rady, Parlamentu Europejskiego, Europejskiego Komitetu Ekonomiczno-Społecznego i Komitetu Regionów: „Zarządzanie powodziowe - zapobieganie powodziom, ochrona przed powodziami i łagodzenie skutków powodzi"41, zwrócono uwagę, że ryzyko powodziowe w UE wzrasta głównie z dwóch powodów: po pierwsze, wskutek zmian klimatycznych, które prowadzić mogą do częstszych ulewnych deszczy i podniesienia poziomu morza jako konsekwencji ocieplenia atmosfery. Drugi czynnik to wpływ działalności człowieka, jak konstrukcje budowane na rzekach i projekty zmiany kierunku oraz uregulowania biegu rzek, budowa portów bez wcześniejszych ocen i działań korygujących ich wpływ na środowisko. Do czynników ludzkich należy też zaliczyć coraz większe pustynnienie naszego kontynentu, który cierpi z powodu masowych wyrębów drzew, pożarów i innych działań sprzecznych z naturą. Ryzyko powodziowe wzrasta na skutek niezrównoważonego rozwoju. Zdaniem Europejskiego Komitetu Ekonomiczno-Społecznego przyjęcie zrównoważonych modeli rozwoju gospodarczego, społecznego i środowiskowego prowadzi do minimalizacji tego ryzyka.

Stanowisko Europejskiego Komitetu Ekonomiczno-Społecznego potwierdza przedmiot wielu rozważań nad celami prawa ochrony środowiska i prawa administracyjnego. Wykrycie i analiza tych celów przybliża nas do zrozumienia istoty prawa ochrony środowiska w łączności z prawem administracyjnym. Wiąże się z tym także naukowe przewidywanie tendencji rozwoju prawa ochrony środowiska i prawa administracyjnego jako dwóch najważniejszych podstaw prawnych zarządzania ryzykiem powodziowym.

\section{UWAGI KOŃCOWE}

Cele prewencyjne „zarządzania ryzykiem powodziowym” w prawie ochrony środowiska są realizowane przez organy ad-

${ }^{41} \operatorname{COM}(2004) 472$ końcowy. 
ministracji rządowej i samorządowej. Użytkownicy wód zobowiązani są do współpracy z organami administracji w ochronie przed powodzią. Ochronę przed powodzią realizuje się, uwzględniając wszystkie elementy zarządzania ryzykiem powodziowym, w szczególności zapobieganie, ochronę, stan należytego przygotowania i reagowanie w przypadku wystąpienia powodzi, usuwanie skutków powodzi, odbudowę i wyciąganie wniosków w celu ograniczania potencjalnych negatywnych skutków powodzi dla zdrowia ludzi, środowiska, dziedzictwa kulturowego oraz działalności gospodarczej. Cele te określa wprost ustawodawca w ustawie p.w. Zasadniczym problemem do rozwiązania w celu osiągnięcia pełnej skuteczności w zarządzaniu ryzykiem powodziowym jest uwzględnienie wszystkich czynników i uwarunkowań środowiskowych mających wpływ na szeroko rozumianą ochronę przed powodzią. Jednym z nich jest racjonalne gospodarowanie wodami. Wydaje się, że współczesna forma prawna organizacji systemu zarządzania ryzykiem powodziowym nie nadaje się do rozwiązania licznych problemów związanych z zapewnieniem kompleksowej ochrony środowiska, przed zagrożeniami wywołanymi przez powodzie. Analiza badań systemu prawa ochrony środowiska w tym zakresie wykazuje pewne zróżnicowanie ustalenia celów kompleksowej ochrony środowiska. Myślenie i działanie na rzecz zapobiegania powodziom powinno przyczynić się do realizacji kompleksowych celów ochrony środowiska w powiązaniu z prawem gospodarczym i prawem administracyjnym. Zarządzanie ryzykiem powodziowym jest jednym z najważniejszych instrumentów prawnych współczesnego zarządzania zasobami środowiska realizującego założenia zasady prewencji w prawie ochrony środowiska.

\section{BIBLIOGRAFIA}

Ackoff R. L., Zasady planowania w korporacjach, przeł. A. Szeworski, Warszawa 1973. 
Biswas A. K., Historia hydrologii, przeł. K. Chomicz-Jung, U. Zalewska-Okrutna, Warszawa 1978.

Gościński J., Zarys teorii sterowania ekonomicznego, Warszawa 1977.

Karpus K., Ochrona przed powodzia i susza, [w:] B. Rakoczy (red.), Wybrane problemy prawa wodnego, LEX 2013, nr 181168.

Kowalewski Z., Nauka a planowanie jej rozwoju, Wrocław-Warszawa-Kraków 1967.

Koźmiński A. K., Obłój K., Strategie zarządzania, [w:] A. K. Koźmiński (red.), Współczesna koncepcje zarządzania, Warszawa 1985.

Koźmiński A. K., Wstęp, [w:] A. K. Koźmiński (red.), Decyzje. Analiza systemowa organizacji, Warszawa 1979.

Król M., Wybrane zagadnienia informatyki prawniczej, [w:] J. Wróblewski (red.), Wstęp do informatyki prawniczej, Warszawa 1985.

Królikowska-Olczak M., Problemy prawne zarządzania działalnościa gospodarcza prowadzona przez kapitalistyczne podmioty gospodarcze $w$ państwach socjalistycznych na przykładzie Polski, Łódź 1990.

Kryński J., Planowanie rozwoju społeczno-gospodarczego, Warszawa 1976.

Lambor J., Podstawy i zasady gospodarki wodnej, Warszawa 1965.

Łętowski J., Administracja, prawo, orzecznictwo sądowe, Wrocław-Warszawa-Kraków-Gdańsk-Łódź 1985.

Maneli M., O funkcjach państwa, Warszawa 1963.

Mikulski Z., Gospodarka wodna, Warszawa 1998.

Mothes J., Sytuacje niepewne a podejmowanie decyzji w przemyśle, przeł. S. Budkowski, Warszawa 1972.

Nietyksza B., Zasady kompensacji szkód z tytułu ryzyka, Warszawa 1971.

Ogerman M., Woda, przeł. R. Budzanowski, R. Romanowicz, Warszawa 1977.

Opałek K., Filozofia prawa a filozofia społeczna, [w: ] H. Groszyk, J. Malarczyk, A. Pieniążek, W. Skrzydło, W. Śladkowski (red.), Problemy teorii i filozofii prawa, Lublin 1985.

Piontek F., Dziadek S., Kusztal J., Łabno Z., Planowanie procesów ochrony i kształtowania środowiska, [w:] S. Jarzębski (red.), Organizacja i funkcjonowanie procesów ochrony środowiska na szczeblu centralnym i regionalnym, Wrocław-Warszawa-Kraków-Gdańsk 1980.

Poskrobko B., Nowe aspekty koncepcji systemu zarządzania środowiskiem, [w:] J. Ejdys, A. Matuszak-Flejszman (red.), Od integracji systemów zarządzania do TQM, Poznań 2003. 
Rotko J., Dział V. Ochrona przed powodziq oraz suszq, [w:] J. Rotko, Prawo wodne. Komentarz, Wrocław 2002.

Rotko J., Ramowa dyrektywa wodna - analiza prawna, Poznań 2013.

Skoczny T., O niektórych problemach teorii zadań administracji państwowej, OMT 1985/11-12.

Stahl M., Cele publiczne i zadania publiczne, [w:] J. Zimmermann (red.), Koncepcja systemu prawa administracyjnego: Zjazd Katedr Prawa Administracyjnego i Postępowania administracyjnego, Zakopane, 24-27 września 2006 r., Warszawa 2007.

Strzyczkowski K., Administracyjnoprawne instytucje planowania, Warszawa 1985.

Supernat J., Instrumenty działania administracji publicznej. Studium z nauki administracji, Kolonia Limited 2003.

Szwed T., Wróblewski T., Zarys inżynierii wodnej, Kraków 1959.

Tuszko A., Gospodarka wodna, Warszawa 1967.

Zieleniewski J., Organizacja i zarządzanie, Warszawa 1969.

Kontakt e-mail:

Pkorzeniowski@wpia.uni.lodz.pl 